\title{
The Role of Pancasila Education in Shaping Youth's Character Towards Golden Indonesia 2045
}

\author{
Erni Dewi Riyanti ${ }^{1(*)}$, Fakhriyah Tri Astuti ${ }^{1}$, Putri Jannatur Rahmah ${ }^{1}$, Haerini Ayatina ${ }^{1}$ \\ ${ }^{1}$ Universitas Islam Indonesia, Kaliurang Street Km. 14.5, Yogyakarta, Indonesia. \\ *Corresponding author. Email: erni.dewi@uii.ac.id
}

\begin{abstract}
Indonesia, with its potentials and resources, is predicted to become one of the most influential countries with the strongest economic growth in 2045. In the same year, Indonesia will celebrate its first centennial anniversary. It is predicted that Indonesia will reach a demography bonus of 100 million-productive age generation. This can actually be a strategic ammunition for Indonesia to achieve the Golden Indonesia in 2045. On the other hand, it can also be a disaster if the generation is not well-prepared. The nation grows based on its Pancasila (the Five Pillars) with values that are capable of building youth character to face the centennial challenges. In this case, higher education institution plays a central role in the formation of youth's characters which should be in-line with the values of Pancasila. This study employs qualitative approach by utilizing written sources as references on observing the role of Pancasila in shaping youth's characters. This study tries to illustrate the way higher education institution builds the characters of youth, especially to face Golden Indonesia in 2045.
\end{abstract}

Keywords: Pancasila education, indonesia golden 2045, character education, higher education.

\section{INTRODUCTION}

Education is a trusted way to shape the best characters in a person. With education, everyone will be able to find and shape the existing characters in themselves, which of these characters will be used as a guide to be able to live their lives. In addition, education is one of the benchmarks to be able to say that a country can be called a developed country, because the benchmark for a good country is a country with a good education sector, which will be a way to be able to build characters of the nation's youth.

This belief brings a dream of Indonesia's achievement exactly 100 years after Indonesia's independence, which in 2045 Indonesia is predicted to become one of the countries with the strongest economic sectors in the world. In 2045, it is predicted that in Indonesia there will be a demographic bonus where the population of productive age will dominate the population of unproductive age. This is the right weapon to realize the ideals of Indonesia in 2045; nonetheless, this can also be a threat to Indonesia if only the resources to deal with this demographic bonus are not well prepared.

Given the current state of Indonesian youth, it can be seen that young people are busier with technicaldramatic issues, results-oriented attitude and usability, making many Indonesian youth think on a capitalist basis rather than philosophical, which is philosophical rights. which will shape the character of Indonesian youth in the future to be able to face a wave of demographic bonus in the next 2045.

In preparing the golden generation to support the ideals of Indonesia in the face of Indonesia 2045, the need for character education is not just a pragmatic theory but also practical and applicable needs. Indonesia itself is a country with high level of diversity, with more than 17,000 islands and thousands of ethnic groups, in the future, it will face problems, like, unity and integrity. Therefore, character education is in accordance with the circumstances and character of Indonesian people themselves. In this case, Indonesia has Pancasila as its basis which contains countless philosophical values. Pancasila will underlie the character education needed by Indonesian people to face challenges in an increasingly erratic era. With character education based on Pancasila, Indonesia will be able to face challenges to reach Golden Indonesia in 2045. Based on Law No. 12/2012, Pancasila is one of the four compulsory education that must be taught at universities in Indonesia and it indicates that Pancasila must be owned and understood by students as agents of change and the next generation of the nation in 2045 .

\section{METHOD}

The method used in writing this paper was using literature studies. This scientific paper uses a descriptive qualitative approach, generally emphasizing data analysis and deepening of the material in answering the problems being faced. (Kisworo \& 
Sofana, 2017) A qualitative approach emphasizes the process of thinking deductively and inductively, where the authors understand the problem in depth with the aim of getting results in the form of solving the problem. Based on the availability of the variables, this research was classified as a descriptive study where existing data analyzed, deeply explored with the help of a scientific thinking framework without manipulating data. (Kisworo \& Sofana, 2017)

Based on the source, the data we obtained were secondary data. Data obtained from the research results from journals and papers published. Additionally, the data also obtained from the results of previous research findings. Secondary data was a type of data collected indirectly, obtained from ready-to-use data (Dharmaseta, 1993, in Asep, et al., 2018). Data collection methods obtained from several scientific ways or steps in finding the subject matter (keywords). Kisworo \& Sofana (2017) assert that there are several research data collection methods, namely observation, interviews, questionnaires, physical measurements, and laboratory experiments. In this paper, the data were taken from secondary data observed from several reputable journals, books, and websites.4. Findings

\section{Pendidikan Pancasila}

Education, according to Binti Maunah in her book titled Educational Platform, is a programmed learning experiences in the form of formal, non-formal, and informal education in school and outside of school that last a lifetime that mainly aims at optimization.

According to $\mathrm{Ki}$ Hajar Dewantara, the notion of education is the process of guiding natural forces that exist in students; thus, they as humans and as members of society can achieve the highest safety and happiness. Good mentions the notion of education is on the process of developing individual skills in community attitudes and behavior. The social process by which a person is influenced by an organized environment, like, home or school, to achieve self-development and social skills.

Pancasila, according to Muhammad Yamin, is originated from the word panca means five and sila means basic, joint, principle, good and important rules of behavior. In this way, Pancasila is the five bases whose contents are the rules or guidelines regarding good and important behavior. In Law No. 20/2003, the notion of education is a conscious and planned effort to create an atmosphere of learning and learning process in which students can actively develop their potential to have spiritual strength, self-control, personality, intelligence, noble character, and the skills needed by themselves, the community, the nation, and country.

Based on the aforementioned theories, education can be defined as the process of taking values from the scope of the family, school, and community to be able to live life as a human being. When Pancasila combined and the notions of education combined, Pancasila education can be defined as the process of taking basic values contained in the philosophy of Pancasila itself, where those basic values are used as a way of life for the Indonesian people.

\section{Indonesian Golden 2045}

Indonesia 2045 is the year that Indonesia celebrates its centennial independence and Golden Indonesia is Indonesia's vision to welcome and prepare to be one of the strongest countries in economic in the world.

Prof. Mahfud MD in his speech explained that, to face Golden Indonesia 2045, the country has some challenges namely moral issues and loyalty to the nation. It can be proven by the incidents and problems, such as, increasing juvenile delinquency, drug use, free sex which by far become serious challenges to realize Golden Indonesia 2045.

It has been predicted that in 2045, Indonesia will experience a demographic bonus. It indicates an increase in the population of productive age and a decrease in the number of unproductive populations. It becomes a weapon for Indonesia if it can prepare adequate human resources. On the other hand, it can be a severe threat to the nation when almost half of its productive population is unable to meet the criteria of productive population.

The golden generation must be prepared to respond the future challenges of an increasingly competitive and globally competitive world. The quality of human resources will determine the fate of Indonesia in the future.

\section{RESULT AND DISCUSSION}

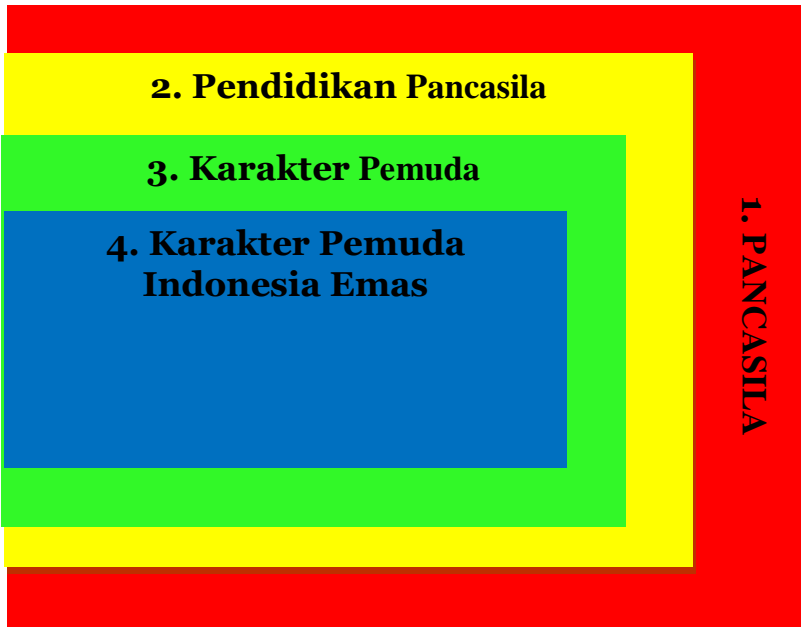


(1) Pancasila has intrinsic values which will directly influence and underlie the components forming youth characters, specifically to be able to face the demographic mode in 2045 and to shape youth character in achieving one of the Indonesia's vision in 2045 namely Golden Indonesia 2045. The Godhead value will underlie the other four values, namely: Fair and civilized values, the value of Indonesian unity, popular values led by wisdom of wisdom in deliberative representation, and the value of social justice for all Indonesian people. When the five values elaborated, there will be new values that can shape the character of Indonesian youth because Pancasila itself is full of values.

(2) Pancasila Education in Law No. 12/2012 explicitly states that Pancasila is one of the compulsory subjects that must be taught at the level of higher education. It indicates that Pancasila is one of the elements that must be comprehended by students as agents of change. The success of character education can be influenced by the techniques or approaches used in teaching-learning process and daily activities. Soetanto (2012) explains that character education in tertiary institutions can be carried out based on the following pillars, namely, Tri Dharma Perguruan Tinggi (the Three Pillars of Higher Education), University Culture or Organizational Culture, Student Activities, Daily Activities, and Academic Culture. The five pillars above are used as an illustration to apply the values of Pancasila education learned by students in their classroom.

(3) With the existence of character education which is in accordance with the conditions and values of Indonesia, the application of Pancasila education in shaping the character of the nation's youth will succeed in forming a golden generation based on Pancasila values, making Indonesian youth (the golden generation) able to face Indonesia's challenges and succeed in reaching the vision of Golden Indonesia in 2045, namely to become one of the countries with the strongest economic growth in the world.

\section{CONCLUSION}

Pancasila with all its values will underlie and animate every community's behavior. Pancasila Education is an education that is aware of and makes Pancasila as the principal values. Pancasila education in higher education institutions as the place for the youth to succeed in the nation, is expected to be able to instill the intrinsic values contained in Pancasila. Pancasila education will create values as a strong fortress for Indonesian in facing and achieving the Golden Indonesia in 2045.

\section{REFERENCES}

Abi, Antonius Remigius. "Paradigma Membangun Generasi Emas Indonesia Tahun 2045" 2 (2015): 85-90.

Baharun, Hasan, Jawa Timur, Siti Maryam, and Jawa Timur. "Building Character Education Using Three Matra of Hasan Al- Banna's Perspective in Pesantren" 4, no. 2 (2019): 51-62. https://doi.org/10.15575/jpi.v4i2.2422.

Jamrah, Alfian. "Shaping Golden Generation Through Character," 2016, 41-50.

Komara, Endang. "Curriculum and Civic Education Teaching in Indonesia" 10, no. August (2017): 23-32.

Maryam, Shovi, Fathiyatul Ummah, Ahmad Munjin, and Ahmad Faris. "1 Hour Q-Time as a Preventive Effort of Juvenile Delinquencies to Prepare the Golden Generation of Indonesia 2045" 164, no. Icli 2017 (2018): 39-46.

Nurdin, Encep Syarief. "The Policies on Civic Education in Developing National Character in Indonesia" 8, no. 8 (2015): 199-209. https://doi.org/10.5539/ies.v8n8p199.

Rokhman, Fathur, M Hum, and Ahmad Syaifudin. "Character Education For Golden Generation 2045 ( National Character Building for Indonesian Golden Years )." Procedia - Social and Behavioral Sciences 141 (2014): 1161-65. https://doi.org/10.1016/j.sbspro.2014.05.197.

Susanti, Rosa. "Penerapan Pendidikan Karakter Di Kalangan Mahasiswa," 1946, 480-87. 